\title{
p16 ${ }^{\text {INK4a }}$ Is Selectively Silenced in the Tumoral Progression of Mycosis Fungoides
}

\author{
Inmaculada C. Navas, Patrocinio Algara, Marisol Mateo, Pedro Martínez, \\ Carmen García, Jose L. Rodriguez, Francisco Vanaclocha, Nuria Barrientos, \\ Luis Iglesias, Lydia Sánchez, Miguel A. Piris, and Pablo Ortiz-Romero \\ Departments of Genetics (ICN, PA, MM, PM) and Dermatology (CG), Virgen de la Salud Hospital, Toledo; \\ Departments of Dermatology (FV, NB, LI, PO-R) and Pathology (JLR), 12 de Octubre Hospital, Madrid; and Centro \\ Nacional de Investigaciones Oncológicas (LS, MAP), Madrid, Spain
}

SUMMARY: Knowledge about the molecular mechanisms involved in the pathogenesis of tumoral progression in mycosis fungoides (MF) is still scarce. Because the 9p21 locus seems to be a good target for a detailed study in MF, this prompted us to compare the mechanisms of inactivation of the $\mathrm{p} 16^{\mathrm{INK} 4 \mathrm{a}}, \mathrm{p} 15^{\mathrm{INK} 4 \mathrm{~b}}$, and $\mathrm{p} 14^{\mathrm{ARF}}$ genes in aggressive and stable forms of MF, performing microsatellite analysis, methylation-specific polymerase chain reaction, direct sequencing, and $\mathrm{p} 16^{\mathrm{INK} 4 \mathrm{a}}$ protein expression by immunohistochemistry. Additionally, the p53 gene was also sequenced in tumoral lesions. Thirty-nine patients with stable MF were studied. Alterations in $\mathrm{p} 16^{\mathrm{INK} 4 \mathrm{a}}$ and $\mathrm{p} 15^{\mathrm{INK} 4 \mathrm{~b}}$ genes were detected in $18 \%$ and $5 \%$ of the cases, respectively. None of the cases analyzed showed alterations of the p14 ARF gene. In contrast with these findings, in the 11 patients with aggressive MF, alterations of the $\mathrm{p} 16^{\mathrm{INK} 4 \mathrm{a}}, \mathrm{p} 15^{\mathrm{INK} 4 \mathrm{~b}}$, or $\mathrm{p} 14^{\mathrm{ARF}}$ genes were found in $8(73 \%), 3(27 \%)$, and 2 (18\%) cases, respectively. A significant proportion (4/11) of these alterations were already present in the p16 $6^{\text {INK4a }}$ gene in the initial plaque lesions in these aggressive forms of MF. Alterations in the $\mathrm{p} 16^{1 \mathrm{NK} 4 \mathrm{a}}$ gene, either methylation or loss of heterozygosity, were clearly more frequent than those in the $\mathrm{p} 15^{\mathrm{INK} 4 \mathrm{~b}}$ and $\mathrm{p} 14^{\mathrm{ARF}}$ genes. These $\mathrm{p} 16^{\mathrm{INK} 4 \mathrm{~A}}$ alterations were confirmed using immunohistochemistry. None of the nine tumoral lesions analyzed showed mutations in exons 1-2 of the p16 ${ }^{\text {INK4a }}$ gene or in exons 5-8 of the p53 gene. These results seem to suggest that 9 p21 alterations, and selectively p16 ${ }^{\text {INK4a }}$ silencing, could be a characteristic phenomenon in MF progression. (Lab Invest 2002, 82:123-132).

\begin{abstract}
$M$ ycosis fungoides (MF) is an indolent subtype of cutaneous T-cell lymphoma that slowly evolves through patch, plaque, and tumor stages before the lymph nodes and visceral organs become involved. The evolution from a disease restricted to the skin towards a widespread disseminated disease may take years or even decades. The timing of this aggressive transformation varies from case to case, thus whereas some patients may show an aggressive course from the beginning, in others the disease follows a protracted course, which suggests that there is some variability in the biologic characteristics of these neoplasms that decides the moment at which the aggressive transformation takes place (Diamandidou et al, 1996).

The 9p21 region encodes the growth suppressor genes $\mathrm{p} 16^{\mathrm{INK} 4 \mathrm{a}}, \mathrm{p} 15^{\mathrm{INK} 4 \mathrm{~b}}$, and $\mathrm{p} 14^{\mathrm{ARF}}$. Alterations in this region are one of the most frequent findings in human cancer (Sherr, 1996). It has been shown that $\mathrm{p} 16^{\mathrm{INK} 4 \mathrm{a}}$ and $\mathrm{p} 14^{\mathrm{ARF}}$, the two alternative products of
\end{abstract}

\section{Received July 3, 2001.}

This work was supported by grants 98/005 and 98/0993 from the Fondo de Investigaciones Sanitarias, Ministerio de Sanidad y Consumo, and the Comision Interministerial de Ciencia y Tecnologia (1FD97-0431), Spain. Address reprint requests to: Dr. Patrocinio Algara, Department of Genetics, Hospital Nacional de Parapléjicos, Finca La Peraleda s/n, 45071 Toledo, Spain.E-mail:palgara@cht.insalud.es the 9p21 region, play key roles in the maintenance of the $\mathrm{Rb}$ and $\mathrm{p} 53$ tumor suppressor pathways, respectively (Ching et al, 1998), whereas $\mathrm{p} 15^{\mathrm{INK} 4 \mathrm{~b}}$ is a mediator of extracellular growth inhibition signals (Hannon and Beach, 1994).

INK4 proteins ( $\mathrm{p} 16^{\mathrm{INK} 4 \mathrm{a}}$ and $\left.\mathrm{p} 15^{\mathrm{INK} 4 \mathrm{~b}}\right)$ specifically bind to and inhibit the cyclin D-dependent kinases (CDKs), CDK4 and CDK6, thus preventing pRb phosphorylation and exit from the G1 phase (Serrano, 1997). In contrast with this, p14 ${ }^{\mathrm{ARF}}$ does not bind to CDKs but interacts and sequesters Mdm2 (Kamijo et al, 1998; Lohrum et al, 2000; Zhang et al, 1998), a protein that has the capacity of promoting p53 degradation and also functionally inactivating $\mathrm{Rb}$, leading to cell cycle arrest (Carnero et al, 2000; Pomeranntz et al, 1998; Weber et al, 1999).

Genetic and epigenetic alterations of the INK4/ARF locus on 9p21 are one of the most frequent molecular alterations observed in human tumorigenesis (Cairns et al, 1995; Kamb et al, 1994). Different mechanisms of inactivation of these genes have been described in different types of human cancer. Homozygous deletions (HD), methylation, and mutation of the INK4/ARF locus have been reported in lymphoid malignancies (Drexler, 1998; Gombart et al, 1995; Herman et al, 1996b; Koduru et al, 1995; Ogawa et al, 1995; Quelle et al, 1997; Siebert et al, 1995), such as lymphoblastic lymphoma/acute lymphoblastic leukemia (Gardie et al, 
1998; Okuda et al, 1995), and in B-cell lymphomas (Baur et al, 1999; Fernandez-Piqueras et al, 1997; Herman et al, 1997; Klangby et al, 1998; MartínezDelgado et al, 1998; Ng et al, 1997), where it has been shown to be involved in the transformation of lowgrade to high-grade tumors (Elenitoba-Johnson et al, 1998; Pinyol et al, 1998; Villuendas et al, 1998).

Methylation of the different genes present in 9p21 seems to be a random phenomenon, which may affect only one of the genes or combinations of them, in a pattern that has been linked to specific types of neoplasms. Thus, concomitant hypermethylation of $\mathrm{p} 16^{\mathrm{INK} 4 \mathrm{a}} / \mathrm{p} 15^{\mathrm{INK} 4 \mathrm{~b}}$ genes, which is unusual in other malignancies (such as myeloblastic leukemia, lymphoblastic leukemia, and glioma) (Aggerholm et al, 1999; Cameron et al, 1999; Herman et al, 1996b), has often recently been detected in multiple myeloma ( $\mathrm{Ng}$ et al, 1999). The p14 ${ }^{\mathrm{ARF}}$ promoter demonstrates selective epigenetic silencing in a subset of colorectal tumors, with a hypermethylated promoter ( $\mathrm{p} 14^{\mathrm{ARF}}$ ) between two unmethylated promoters ( $\mathrm{p} 16^{\mathrm{INK} 4 \mathrm{a}}$ and $\mathrm{p} 15^{\mathrm{INK} 4 \mathrm{~b}}$ ) that in contrast are frequently methylated in other tumor types (Esteller et al, 2000). Recent studies (Baur et al, 1999) have observed the absence of p14 ARF gene mutations or methylation in all lymphomas analyzed, which suggests that $\mathrm{p} 14^{\mathrm{ARF}}$ inactivation is not implicated in human lymphomagenesis or could be dependent on additional and varied mechanisms.

The molecular mechanisms underlying the progression of MF into tumoral stage, a phenomenon usually associated with large cell transformation and aggressive behavior, are not well known. Several articles have shown a low frequency of genetic alterations associated with p53, lyt10, c-myc, bcl-1, and bcl-2 genes in patients with MF (de Misa et al, 1995; Garatti et al, 1995). Recently, Scarisbrick et al (2000) found loss of heterozygosity ( $\mathrm{LOH}$ ) on $10 \mathrm{q}$ and microsatellite instability in advanced cutaneous stages of MF, suggesting that a tumor suppressor gene or genes in this region may be associated with disease progression. $A$ recent report by Marrogi et al (1999) described a high frequency of p53 mutations in tumoral MF samples, but this has not been confirmed in other series (Garatti et al, 1995).

Concerning the role of the 9p21 locus, Peris et al (1999) have shown a lack of $p 16^{\text {INK4a }}$ protein expression in patients with MF, suggesting that alterations in this gene might play a pathogenic role in this type of cutaneous lymphoma. Moreover, a previous report by our group (Navas et al, 2000) showed that alterations of $\mathrm{p} 16^{\mathrm{INK} 4 \mathrm{a}}$ are frequent in MF cases with aggressive transformation, but we were unable to determine whether $\mathrm{p} 16^{\mathrm{INK} 4 \mathrm{a}}$ silencing is a frequent and early finding in all cases of MF or only in the subset of cases showing progression. In the first instance, p16 1 NK4a alterations could be a characteristic finding of the disease, whereas in the second, p16 ${ }^{\mathrm{INK} 4 \mathrm{a}}$ silencing would be a risk factor for disease progression. On the other hand, information about $\mathrm{p} 14^{\mathrm{ARF}}$ and $\mathrm{p} 15^{\mathrm{INK} 4 \mathrm{~b}}$ status in MF is scarce.

The aim of this study was to investigate the hypothetical pathogenic role of $\mathrm{p} 16^{\mathrm{INK} 4 \mathrm{a}}, \mathrm{p} 15^{\mathrm{INK} 4 \mathrm{~b}}$, and $\mathrm{p} 14^{\mathrm{ARF}}$ inactivation in a group of stable MF patients (patch/plaque lesions that had not progressed after a minimum of 30 months of follow-up), comparing them with aggressive MF before and after progression.

\section{Results}

\section{Clinical Data}

The clinical data of the patients with stable and aggressive MF are summarized in Table 1.

There were 11 patients with aggressive MF. All of them developed tumoral lesions mostly evidenced by

Table 1. Summary of the Clinical Data of our Patients

\begin{tabular}{|c|c|c|}
\hline & Stable MF & Aggressive MF \\
\hline Number of cases & $n=39$ & $n=11$ \\
\hline Sex distribution & $M / F=20 / 19$ & $M / F=6 / 5$ \\
\hline Mean age at beginning (range) & $\begin{array}{l}41.3 \mathrm{yr} \\
(4-91)\end{array}$ & $\begin{array}{l}42.6 \mathrm{yr} \\
(27-70)\end{array}$ \\
\hline Mean time until biopsy sample analyzed (range) ${ }^{a}$ & $\begin{array}{l}108.6 \mathrm{mo} \\
(3-360)\end{array}$ & $\begin{array}{l}\text { Plaque: } 111.6 \text { mo (6-288) } \\
\text { Tumors: } 121.5 \text { mo }(6-298)\end{array}$ \\
\hline Maximum stage & $\begin{array}{l}\mathrm{T} 1=13 \\
\mathrm{~T} 2=26\end{array}$ & $\begin{array}{l}\mathrm{IIb}=6 \\
\mathrm{IVa}=3 \\
\mathrm{IVb}=2\end{array}$ \\
\hline \multicolumn{3}{|l|}{ Status (January 2001) ${ }^{b}$} \\
\hline Complete remission & 11 & 3 \\
\hline T1NOMO & 18 & 0 \\
\hline T2NO/1MO & 9 & 4 \\
\hline T3anyNanyM & 0 & 3 \\
\hline Dead of lymphoma & 0 & 1 \\
\hline Dead not of lymphoma & $1^{c}$ & $1^{d}$ \\
\hline
\end{tabular}

Stable MF, patients with patch/plaque lesions without tumoral transformation; Aggressive MF, patients that have suffered tumoral transformation.

${ }^{a}$ Months from the beginning of the disease until biopsy of the analyzed sample.

${ }^{b}$ Number of cases.

${ }^{c}$ Small cell lung carcinoma.

${ }^{d}$ Brain tumor. 
large tumoral cells. Sex distribution was M/F:6/5. Mean age at the beginning of MF was 42.6 (range, 27-70) years; mean delay to diagnosis was 42 (range, 3-168) months. The mean time until the appearance of tumors was 94.4 (range 0-298) months. Two patients developed tumors and patch/plaques simultaneously. In another patient, tumors appeared within 6 months of the beginning of plaque lesions.

In four patients the patch/plaque and tumoral samples were taken simultaneously. In five patients, patch/plaque samples were taken 10 to 94 months before sampling of tumoral lesions. In two of them, samples of tumoral lesions were taken 7 and 24 months before the plaque lesion. Patient MF90 died of lymphoma. Patient MF122 died of a pulmonary small cell cancer. The rest of the patients are still alive. Three of the patients (MF36, MF82, and MF79) achieved complete remission $(\mathrm{CR})$, and they remain free of disease after 41, 101, and 16 months of follow-up, respectively. Only three remaining patients (MF73, MF78, and MF91) underwent CR during their medical history, at 6,11 , and 8 months, respectively.

\section{Molecular Studies}

A table showing the results obtained by analysis of the $\mathrm{p} 16^{\mathrm{INK} 4 \mathrm{a}}, \mathrm{p} 15^{\mathrm{INK} 4 \mathrm{~b}}$, and $\mathrm{p} 14^{\mathrm{ARF}}$ genes in stable and aggressive MF is included (Table 2).

In patients with stable MF, alterations of the p16 ${ }^{\text {INK4a }}$ gene were detected in 7 (18\%) of 39 and alterations of the $\mathrm{p} 15^{\mathrm{INK} 4 \mathrm{~b}}$ gene were detected in 2 $(5 \%)$ of 39 of the lesions. None of the 39 cases analyzed showed alterations of the p14 ${ }^{\mathrm{ARF}}$ gene. Only methylation of some of these genes was observed, and no genetic loss was detected.

In contrast with these results, in patients with aggressive MF (11 cases), alterations of the $\mathrm{p} 16^{\mathrm{INK} 4 a}$ gene were found in 8 (73\%) of 11 tumoral samples (2 cases of allelic loss [MF36, MF113] and 6 of methylation); alterations of the $\mathrm{p} 15^{\mathrm{INK} 4 \mathrm{~b}}$ gene were found in 3 (27\%) of 11 samples (2 cases of allelic loss [MF36, MF113] and 1 of methylation); and alterations of the p14 ${ }^{\mathrm{ARF}}$ gene were found in $2(18 \%)$ of 11 samples (2 cases of allelic loss [MF36 and MF113]). All of these alterations were present in the tumoral phase. When analyzing the plaque stage of these aggressive MF, alterations of the $\mathrm{p} 16^{\mathrm{INK} 4 \mathrm{a}}$ gene were found in 4 (36\%) of 11 samples ( 1 allelic loss and 3 methylation); alterations of the $\mathrm{p} 15^{\mathrm{INK} 4 \mathrm{~b}}$ gene were found in 2 (20\%) of 10 samples (1 case of allelic loss and 1 of methylation); and alterations of the $\mathrm{p} 14^{\mathrm{ARF}}$ gene were found in $1(10 \%)$ of 10 samples (1 allelic loss) (Table 3 ).

\section{Allelic Loss Studies}

In 21 cases of patients with stable MF, DNA was available from nontumoral tissue for the analysis of microsatellites surrounding the $\mathrm{p} 16^{\mathrm{INK} 4 \mathrm{a}}, \mathrm{p} 15^{\mathrm{INK} 4 \mathrm{~b}}$, and $\mathrm{p} 14^{\mathrm{ARF}}$ genes in the 9p21 region. None of the 21 cases analyzed showed allelic loss.

In contrast with this finding, in patients with aggressive MF, 3 of 11 samples taken in the tumoral phase showed genetic loss, 1 showed HD, and 2 showed $\mathrm{LOH}$. In one of these cases (MF39), LOH was detected in only two contiguous markers, without including the $\mathrm{p} 16^{\mathrm{INK} 4 \mathrm{a}}, \mathrm{p} 15^{\mathrm{INK} 4 \mathrm{~b}}$, and $\mathrm{p} 14^{\mathrm{ARF}}$ genes. Some of these data have been previously published (Navas et al, 2000) (Fig. 1; Table 3).

\section{Aberrant Methylation at the 5'-CpG Islands in 9p21 Gene Cluster}

The methylation status of the $\mathrm{p} 16^{\mathrm{INK} 4 \mathrm{a}}, \mathrm{p} 15^{\mathrm{INK} 4 \mathrm{~b}}$, and $\mathrm{p} 14^{\mathrm{ARF}} \mathrm{CpG}$ islands was investigated in $58 \mathrm{MF}$ samples (Fig. 2).

Methylation of the $\mathrm{p} 16^{\mathrm{INK} 4 \mathrm{a}}$ gene was found in only $7(18 \%)$ of 39 lesions from cases of stable MF, whereas it was observed in $6(60 \%)$ of 10 tumoral samples from cases of aggressive MF. When analyzed, plaque lesions of aggressive forms of MF showed an intermediate value, and 3 (33\%) of 9 of cases were positive. Some of these data have been previously published (Navas et al, 2000).

Methylation of the $\mathrm{p} 15^{\mathrm{INK} 4 \mathrm{~b}}$ gene was found in 2 (5\%) of 39 cases of stable MF. In aggressive MF, p15 INK4b hypermethylation was observed in 2 (20\%) of 10 cases, associated in both with p16 methylation. No case showed $\mathrm{p} 14^{\mathrm{ARF}}$ gene methylation (Table 3 ).

All of the 35 negative controls included (skin, lymphoid tissue in different reactive conditions, and peripheral blood lymphocytes) showed amplification with unmethylated-specific primers (U) but not with methylated-specific primers (M).

\section{Mutational Analysis}

To determine whether mutations of the p16 ${ }^{\mathrm{INK} 4 \mathrm{a}}$ and p53 gene were present, exons 1 and 2 and 5 to 8 of these genes, respectively, were analyzed by direct sequencing. None of the nine cases studied, all of which corresponded to tumoral lesions, showed mutations in any of the genes.

\section{Immunohistochemical Studies}

Immunohistochemical studies for $\mathrm{p} 16^{\mathrm{INK} 4 \mathrm{a}}$ were performed on paraffin-embedded tissue samples from 39

Table 2. Summary of $\mathrm{p} 16^{\mathrm{INK} 4 \mathrm{a}}, \mathrm{p} 15^{\mathrm{INK} 4 \mathrm{~b}}$, and $\mathrm{p} 14^{\mathrm{ARF}}$ Gene Alterations in MF

\begin{tabular}{lcccc}
\hline & \multirow{2}{*}{$\begin{array}{c}\text { Total alterations } \\
\text { sumples }\end{array}$} & p16 & $\mathrm{p} 15^{\text {INK4b }}$ & $\mathrm{p} 14^{\text {ARF }}$ \\
\hline Aggressive MF & 11 & $8(73 \%)$ & $3(27 \%)$ & $2(18 \%)$ \\
Stable MF & 39 & $7(18 \%)$ & $2(5 \%)$ & 0 \\
\hline
\end{tabular}

Includes both methylation and deletion analysis. 
Table 3. Summary of 9p21 Region Alterations in the Plaque and Tumoral Stages of Aggressive MF

\begin{tabular}{|c|c|c|c|c|c|c|c|c|c|}
\hline \multirow[b]{3}{*}{ Cases } & \multicolumn{6}{|c|}{ Methylation } & & & \multirow{3}{*}{$\frac{\text { Mutation } \mathrm{p} 16^{\text {INK4a }}}{\text { Tumor }}$} \\
\hline & \multicolumn{2}{|c|}{ p16 INK4a } & \multicolumn{2}{|c|}{$\mathrm{p} 15^{\mathrm{INK} 4 \mathrm{~b}}$} & \multicolumn{2}{|c|}{$\mathrm{p} 14^{\mathrm{ARF}}$} & \multicolumn{2}{|c|}{ Allelic loss 9p21 } & \\
\hline & Plaque & Tumor & Plaque & Tumor & Plaque & Tumor & Plaque & Tumor & \\
\hline${\mathrm{MF} 36^{a}}^{a}$ & ND & - & ND & - & ND & - & - & $\mathrm{HD}$ & $\mathrm{wt}^{b}$ \\
\hline MF39a & + & + & + & ND & - & ND & - & $\mathrm{LOH}^{c}$ & ND \\
\hline $\mathrm{MF73}^{\mathrm{a}}$ & - & + & ND & - & ND & - & ND & - & wt \\
\hline MF78 ${ }^{a}$ & - & + & - & - & - & - & ND & - & wt \\
\hline MF79 & - & + & - & - & - & - & - & - & wt \\
\hline MF91 ${ }^{a}$ & + & + & - & + & - & - & - & - & wt \\
\hline$M F 113^{a}$ & - & - & - & - & - & - & $\mathrm{LOH}$ & LOH & wt \\
\hline MF122a & + & + & - & - & - & - & - & - & wt \\
\hline MF82a & - & - & ND & - & ND & - & - & - & wt \\
\hline $\mathrm{MF90}^{a}$ & ND & ND & ND & ND & ND & ND & - & - & ND \\
\hline MF172 & - & - & - & - & - & - & - & - & wt \\
\hline Alterations & $3 / 9$ & $6 / 10$ & $1 / 7$ & $1 / 9$ & $0 / 7$ & $0 / 9$ & $1 / 9$ & $3 / 11$ & $0 / 9$ \\
\hline
\end{tabular}

HD, homozygous deletion; LOH, loss of heterozygosity; ND, not done; +, positive; -, negative.

${ }^{a}$ The results corresponding to the $\mathrm{p} 16^{\text {INK4a }}$ gene of these patients have been published previously (including deletion, mutation, and methylation analysis) (Navas et al, 2000).

${ }^{b}$ wt due to reactive cells associated with the tumor as it presents HD.

${ }^{c}$ In case MF39, LOH was detected in two markers, without including $\mathrm{p} 16^{\mathrm{INK} 4 \mathrm{a}}, \mathrm{p} 15^{\mathrm{INK} 4 \mathrm{~b}}$, and $\mathrm{p} 14^{\mathrm{ARF}}$ genes (Navas et al, 2000).

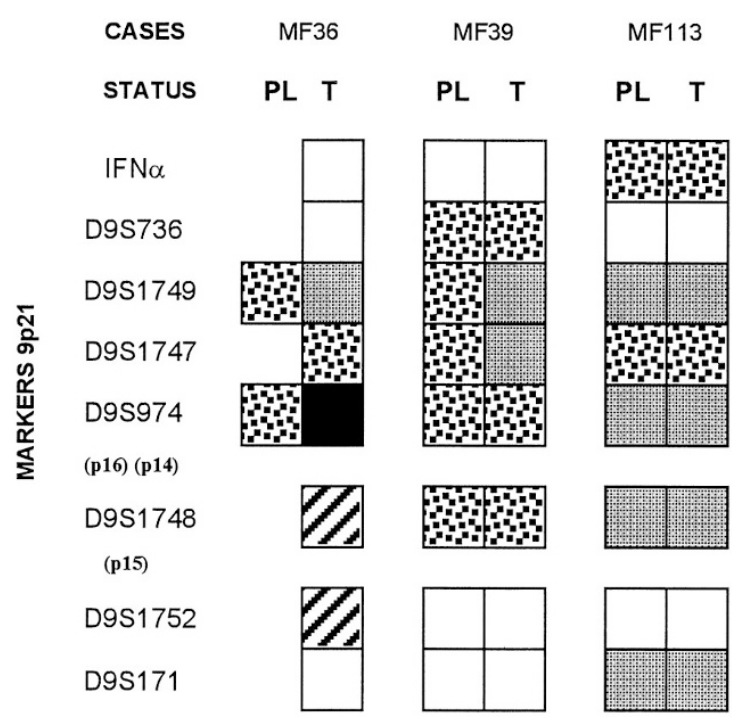

Figure 1.

Summary of microsatellite analysis of locus $9 p 21$ in aggressive mycosis fungoides (MF). Three samples that showed deletions at one or more loci are presented. All of them are illustrated in plaque (PL) and tumoral (T) stages. The status of each chromosomal locus is indicated as follows: $\mathbf{0}$, homozygous deletion; 圈, loss of heterozygosity; 圈, retention of both alleles; $\square$, noninformative; $\mathbb{Z}$, noninformative loci with a signal markedly diminished in comparison with DNA normal.

patients. Loss of $\mathrm{p} 16^{\mathrm{INK} 4 \mathrm{a}}$ expression was observed in 12 of 39 cases, 7 of them characterized by $\mathrm{p} 16^{\text {INK4a }}$ promoter methylation and 5 cases, scored as p16 $16^{\text {INK4a }}$ negative in the Table 4, and lacking molecular alterations (2/5 cases showed a mixture of positive and negative cells). In 27 cases, intraepithelial and atypical lymphocytes showed a nuclear distinct expression, comparable to that seen in the epithelial cells. Representative cases are illustrated in Figure 3.

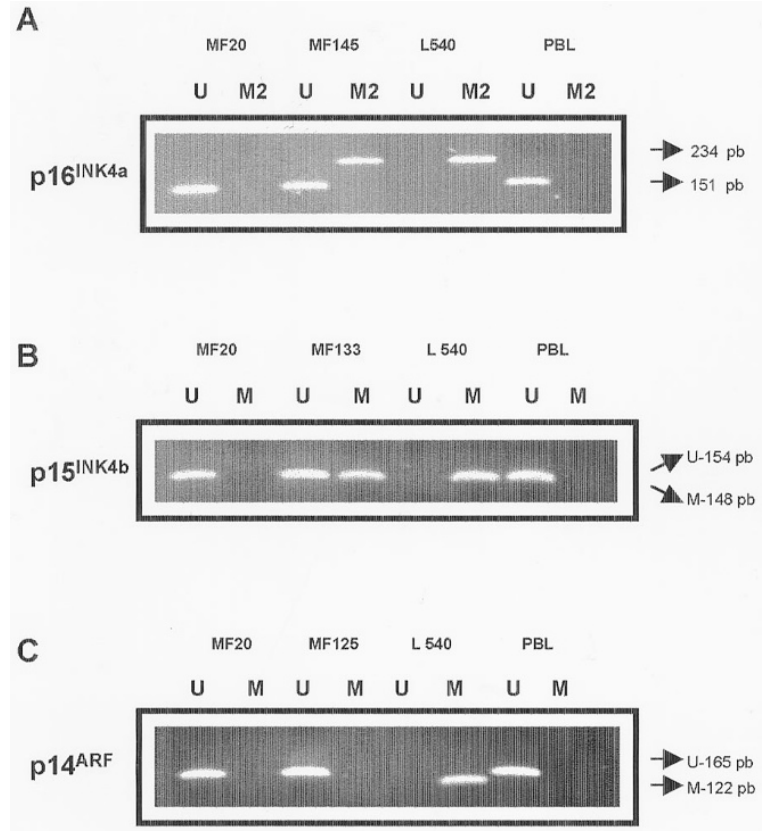

Figure 2.

Methylation-specific PCR assay of the p16 ${ }^{\text {INK4a }}(A), p 15^{\text {INK4b }}(B)$, and p14 ARF (C) gene. Agarose gel electrophoresis of some representative cases with stable MF is shown. Primer sets used for amplification are designated as unmethylated (U) or methylated (p16-M2, p15-M, and p14-M). The Raji cell line and peripheral blood lymphocytes (PBL) serve as positive controls for methylated (M2/M) and unmethylated (U) p16 ${ }^{\text {INK4a }}, \mathrm{p} 15^{\mathrm{INK} 4 \mathrm{~b}}$, and $\mathrm{p} 14^{\mathrm{ARF}}$ alleles, respectively.

\section{Correlation Between Clinical and Molecular Data}

We statistically compared the 39 patients with stable MF and the 11 patients with aggressive MF (Wilcoxon and median score tests). We could find no significant differences between the two populations in terms of 
Table 4. Relationship Between the Results of IHC of p16 Protein and $\mathrm{p} 16^{\text {INK4a }}$ Gene Status in Samples from Patients with MF

\begin{tabular}{ccc}
\hline & \multicolumn{2}{c}{$\mathrm{p} 16^{\text {INK4a }}$ gene status } \\
\cline { 2 - 3 } $\mathrm{p} 16^{\text {INK4a }}$ IHC & Altered & Nonaltered \\
\hline Negative & 7 & 5 \\
Positive & 0 & 27 \\
\hline
\end{tabular}

IHC, Immunohistochemistry.

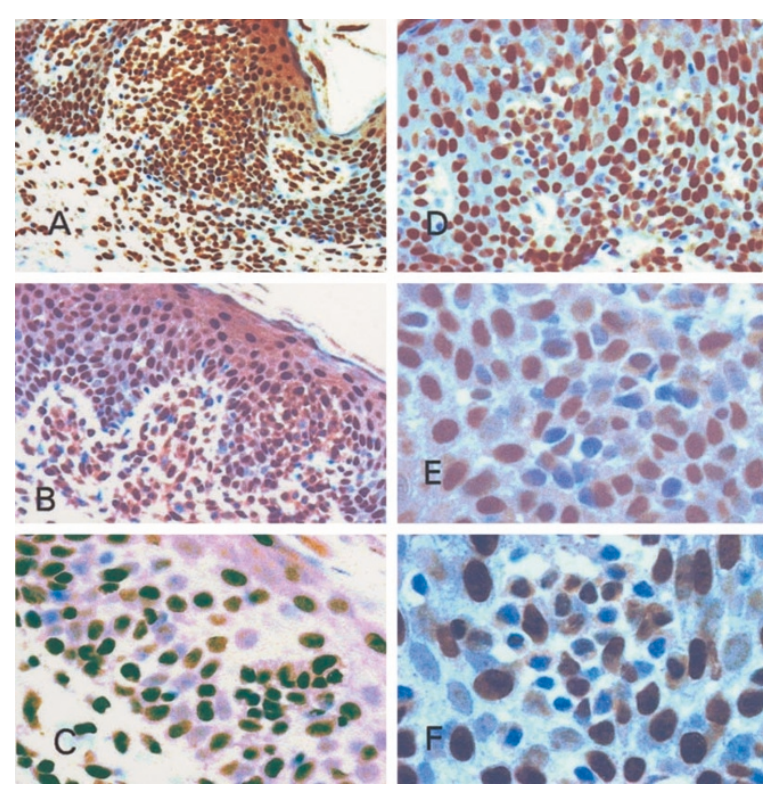

Figure 3.

p16 $6^{\text {INK4a }}$ immunohistochemistry showing three positive cases $(A-C)$ and three negative cases (D-F).

sex distribution, age at onset, the mean time interval between the first clinical manifestation of MF and the date of the biopsy, time of follow-up after the biopsy specimen was analyzed, or treatments performed before the biopsy specimen was analyzed. Both populations were homogeneous.

We then analyzed the frequency of inactivation of the different genes, when comparing stable and aggressive forms of MF. When we investigated $\mathrm{p} 16^{\mathrm{INK} 4 \mathrm{a}}$ inactivation (secondary to both genetic loss and/or hypermethylation), we found that the frequency of p $16^{\text {INK4a }}$ inactivation was significantly higher in tumoral lesions corresponding to aggressive MF (8/11, $73 \%$ ). In comparison with this, in the biopsy specimens taken from the stable form of MF, p16 $16^{\text {INK } 4 a}$ inactivation was present in 7 (18\%) of 39 cases. The comparison between the tumoral lesions of aggressive MF and the stable MF yielded statistically significant differences ( $p=0.001$, Fisher's exact test). This difference was also present when only hypermethylation was analyzed ( $6 / 10$ vs. $7 / 38 ; 60 \%$ vs. $18 \%)(p=$ 0.01 , Fisher's exact test).

Plaque lesions of those patients who developed an aggressive form of MF also showed more frequent p16 ${ }^{\text {INK } 4 \text { a }}$ inactivation (4 [36\%] of 11 cases) than stable plaque lesions (7 [18\%] of 39 cases). This was not statistically significant.

\section{Status of Stable MF with 9p21 Alterations}

There were no statistical differences in the epidemiologic data of the patients with stable MF, whether p16 ${ }^{\text {INK4a }}$ was hypermethylated or not.

Two patients presented $\mathrm{p} 15^{\mathrm{INK} 4 \mathrm{~b}}$ hypermethylation. One patient then was under RePUVA treatment when she underwent biopsy, whereas the other was not receiving any treatment. They remain alive in the Ila and la stages, respectively.

Seven patients presented $\mathrm{p} 16^{\mathrm{INK} 4 \mathrm{a}}$ hypermethylation. Three of them are in Stage la, one is in Stage lb, and three are in complete remission. One patient had associated lymphomatoid papulosis. Three patients were receiving topical corticosteroids when they underwent biopsy. The rest were not being treated.

\section{Discussion}

MF is a cutaneous T-cell lymphoma whose clinical and morphologic characteristics have been thoroughly described. However, despite the high frequency of aggressive transformation in this disease, knowledge of the molecular mechanisms involved in pathogenesis of the tumoral progression is still scarce. The 9p21 locus seems to be a good target for a detailed study in MF, because some previous studies on cutaneous T-cell lymphoma have already pointed out some of the genes present in this chromosomal region. Thus deletions in this area have been characterized by Ogawa et al (1995) and Stranks et al (1995) in two cases of Sézary syndrome; Peris et al (1999) showed a reduced expression of p16 $16^{\text {INK4a }}$ in MF lesions, and our own group (Navas et al, 2000) has shown a relatively high frequency of $\mathrm{p} 16^{\mathrm{INK} 4 \mathrm{a}}$ inactivation when only aggressive forms of MF were analyzed. Nevertheless, so far no study has compared the frequency of inactivation of the different genes codified in 9p21 between aggressive versus quiescent forms of cutaneous T-cell lymphoma, which could eventually point out key targets for the prediction of progression and therapeutic intervention.

This study had the aim of supplying this information, by comparing the status of $\mathrm{p} 16^{\text {INK4a }}, \mathrm{p} 15^{\mathrm{INK} 4 \mathrm{~b}}$, and p1 ${ }^{\mathrm{ARF}}$ genes in a large series of aggressive MF with a group of 39 cases of stable MF, as defined by the absence of progression in a minimum follow-up of 30 months.

Alterations in the $\mathrm{p} 16^{\mathrm{INK} 4 \mathrm{a}}$ gene were clearly more frequent than in the $\mathrm{p} 15^{\mathrm{INK} 4 \mathrm{~b}}$ and $\mathrm{p} 14^{\mathrm{ARF}}$ genes. Inactivation of the $\mathrm{p} 16^{\mathrm{INK} 4 \mathrm{a}}$ gene (hypermethylation or deletion) was found in $18 \%(7 / 39)$ of the lesions of stable MF versus $73 \%(8 / 11)$ of the tumoral lesions of aggressive MF. Statistical analysis was able to detect significant differences when comparing plaque lesions of stable MF with tumoral lesions of aggressive MF ( $p$ $=0.001$, Fisher's exact test). This finding is parallel with those obtained in B-cell lymphomas, where silencing of $\mathrm{p} 16^{\mathrm{INK} 4 \mathrm{a}}$ has been found to play a critical 
role in tumoral progression (Elenitoba-Johnson et al, 1998; Pinyol et al, 1998; Villuendas et al, 1998).

The frequency of $\mathrm{p} 16^{\mathrm{INK} 4 \mathrm{a}}$ alterations in the plaque lesions of those cases that go on to show tumoral transformation $(36 \%)$ was also higher than in the plaque lesions of stable MF (18\%), although these differences did not attain statistical significance. Similarly, the frequency of $\mathrm{p} 16^{\mathrm{INK} 4 \mathrm{a}}$ alterations was higher in tumoral lesions (73\%) than it was in plaque lesions of aggressive MF (36\%), but these differences were not significantly different either. The relatively small size of our series can make proportions that practically double each other statistically insignificant. These data are compatible with the hypothesis that $\mathrm{p} 16^{\mathrm{INK} 4 \mathrm{a}}$ inactivation could be a necessary step for tumoral progression of MF, but additional changes are required to allow or accelerate the progression, because as shown, not all cases with $16^{\text {INK4a }}$ inactivation necessarily progress to aggressive forms during the length of this study.

We have also taken into account the possibility that the lower frequency of $\mathrm{p} 16^{\mathrm{INK} 4 \mathrm{a}}$ alterations in plaque lesions may only reflect a smaller population of tumoral cells within lesions of this kind. We therefore performed sensitivity assays that showed that the methylation-specific PCR (MSP) technique used was able to detect methylation when the amount of tumoral cells was $0.5 \%$ for $\mathrm{p} 16^{\mathrm{INK} 4 \mathrm{~A}}, 10 \%$ for $\mathrm{p} 15^{\mathrm{INK} 4 \mathrm{~b}}$, and $2.5 \%$ for $\mathrm{p} 14^{\mathrm{ARF}}$ (data not shown). The samples analyzed here included the necessary amount of tumoral cells, as assessed by morphologic and immunohistochemical staining. Thereafter, the use of immunohistochemical staining for $\mathrm{p} 16^{\mathrm{INK} 4 \mathrm{~A}}$ has made it possible to confirm the results obtained by $\mathrm{LOH}$ and MSP, with only a minor exception, two cases with a mixture of $\mathrm{p} 16^{\mathrm{INK} 4 \mathrm{~A}}$-positive and -negative cells. Additionally, the percentage of tumoral cells in plaque stage MF was previously found to exceed the threshold of sensitivity of a PCR technique for detection of TCR- $\gamma$ rearrangements, located in $10 \%$ of tumoral cells (Algara et al, 1994).

A relatively low frequency of changes involving $\mathrm{p} 15^{\mathrm{INK} 4 \mathrm{~B}}$ genes were observed in this study, and additionally in aggressive MF no case was observed to harbor changes exclusively in the $\mathrm{p} 15^{\mathrm{INK} 4 \mathrm{~b}}$ gene, because all cases showed concomitant alteration of the $\mathrm{p} 16^{\mathrm{INK} 4 \mathrm{a}}$ gene. Thus alterations of the $\mathrm{p} 15^{\mathrm{INK} 4 \mathrm{~b}}$ gene (deletion and methylation) were observed in 2 $(5 \%)$ of 39 patients with stable MF and in $3(27 \%)$ of 11 of tumoral samples. Consistent with these results, and in concordance with previous observations in which HDs at 9p21 generally occur at a low frequency in non-Hodgkin's lymphomas (Drexler, 1998; Gombart et al, 1995; Koduru et al, 1995; Ogawa et al, 1995; Siebert et al, 1995; Uchida et al, 1995), only one case in this series (MF36) showed HD in the p16 $6^{\mathrm{INK} 4 a}$, $\mathrm{p} 15^{\mathrm{INK} 4 \mathrm{~b}}$, and $\mathrm{p} 14^{\mathrm{ARF}}$ genes. It seems that at least in this tumoral model, the concurrent inactivation of the $\mathrm{p} 16^{\mathrm{INK} 4 \mathrm{a}}$ and $\mathrm{p} 15^{\mathrm{INK} 4 \mathrm{~b}}$ genes just gives a relatively small additional advantage on tumoral cells, thus confirming the diversity of situations observed in lymphomas when analyzing the 9p21 genes (Baur et al,
1999; Drexler, 1998; Elenitoba-Johnson et al, 1998; Pinyol et al, 1998; Villuendas et al, 1998). It is, nevertheless, noteworthy that the two cases with double inactivation of both $\mathrm{p} 16 / \mathrm{Rb}$ and ARF/p53 pathways showed an aggressive form of the disease, as could be predicted.

Generally speaking, these results seem to support that tumoral progression in MF is associated with a very high frequency of $\mathrm{p} 16 / \mathrm{Rb}$ pathway silencing and preservation of the ARF/p53 pathway, as is shown by the rarity of $\mathrm{p} 53$ mutation or $\mathrm{p} 14^{\mathrm{ARF}}$ silencing. Strikingly, p53 alterations were not observed in any case in this series, which contrasts with data published previously by Marrogi et al (1999). No explanation is suggested for this difference, because all cases in our series were sequenced from exon 5 to 8 , the same area where p53 mutations were observed in the study by Marrogi et al (1999).

The tumoral progression of MF may be related to alternative additional mechanisms. Cytokines are believed to play an important role in the pathogenesis of cutaneous T-cell lymphoma (Rook et al, 1997). MF progression has been associated with significantly higher IL-10 and lower IFN- $\gamma$ mRNA expression (Asadullah et al, 1996) suppressing normal T-cell activity and giving the malignant $T$ cells a growth advantage. Several mechanisms may therefore contribute to tumor progression, and the likelihood of a single factor being solely responsible is probably low.

Unfortunately, the results of this study do not make it possible to conclusively predict whether a de novo patient with MF will show an accelerated phase, using only examination of $\mathrm{p} 16^{\mathrm{INK} 4 a}$ status. However, because the hypermethylation of the $\mathrm{p} 16^{\mathrm{INK} 4 \mathrm{a}}$ promoter was the preferred mechanism of inactivation of the p16 INK4a gene in our patients, it suggests that efforts aimed at reversing the methylation status of $\mathrm{p} 16^{\mathrm{INK} 4 \mathrm{a}}$ could have a positive impact on the evolution of the disease. In the future, demethylating agents-such as decitabine, or others-could be used to design clinical assays in this group of patients (Wijermans et al, 2000).

\section{Material and Methods}

\section{Case Selection}

A group of patients with MF was selected from the medical records of the 12 de Octubre Hospital, Madrid, and the Virgen de la Salud Hospital, Toledo (both of which are in the center of Spain). Diagnosis was based on generally accepted clinicopathologic criteria. Patch or plaque lesions were erythematous, slightly scaling macules or plaque lesions with welldefined borders. Histopathologically they presented a characteristic infiltrate of epidermotropic atypical $T$ cells with convoluted cerebriform nuclear contours. Tumors were defined as nodules, whether or not they were ulcerated, with a majority of large cells on histopathologic examination.

We defined "stable MF" as cases that had not progressed into tumoral stages in at least 30 months 
of follow-up after the biopsy. We could obtain freshfrozen material from 39 stable MF cases with patches/ plaques (13 T1, 26 T2). Until January 2001 the minimum follow-up without progression into tumoral stage was 34 months. "Aggressive MF" was defined as cases that progressed into tumoral stage. We identified 11 MF cases from which we could obtain formalin-fixed paraffin-embedded tissue or freshfrozen material from patch/plaque as well as tumoral lesions. Some patients had patch/plaque and tumoral lesions present simultaneously on different areas on their skin. Some of the findings concerning nine of these cases have been published previously (Navas et al, 2000). All of the samples analyzed were studied in parallel for routine hematoxylin-eosin examination.

Complete remission is defined as no evidence of residual disease after a follow-up of at least 3 months. The TNM staging system was used, as defined by the MF Co-operative Group of Mycosis Fungoides/Sézary Syndrome.

\section{Immunohistochemistry}

Sections were cut to a thickness of $3 \mu \mathrm{m}$, dried for 16 hours at $56^{\circ} \mathrm{C}$ before being dewaxed in xylene and rehydrated through a graded ethanol series to PBS. Antigen retrieval was heat mediated in a pressure cooker treated for 2 minutes in $10 \mathrm{~mm}$ citrate buffer $(\mathrm{pH}$ 6.5). Before staining the sections, endogenous peroxidase was blocked.

Immunohistochemical staining of $\mathrm{p} 16^{\mathrm{INK} 4 \mathrm{a}}$ was performed with p16 ${ }^{\text {INK4a }}(\mathrm{F} 12)$ monoclonal antibody (Santa Cruz Biochemicals, Santa Cruz, California) diluted at 1:50. Immunodetection was performed with biotinylated antimouse immunoglobulins, followed by peroxidase-labeled streptavidin, LSAB-2 (DAKO, Glostrup, Denmark) with diaminobenzidine chromogen as substrate. Sections were counterstained with hematoxylin. Incubation omitting the specific antibody, as well as with unrelated antibodies, was used as a control of the technique. A positive control was included with each batch of staining to ensure consistency between consecutive runs.

Results were interpreted according to established criteria (Geradts et al, 1995, 1998; Kratzke et al, 1996), and cases were considered negative (abnormal expression) if a large majority of intraepithelial $T$ cells were $\mathrm{p} 16^{\mathrm{INK} 4 \mathrm{a}}$ negative, contrasting with the positive staining observed in epithelial cells. These criteria reproduce those previously used in the assessment of p $16^{\text {INK4a }}$ reactivity in lymphoma and other tumors (Cohen and Geradts, 1997; Gulley et al, 1998; Reed et al, 1996; Villuendas et al, 1998), and closely reflect the results obtained using a quantitative measurement system in this series (data not shown).

\section{Molecular Studies}

DNA Extraction. Genomic DNA from the cases selected was obtained from frozen or paraffinembedded tissue from patch/plaque and tumoral lesions. For methylation studies, DNA obtained from different samples of reactive lymphoid tissue (25 cases of peripheral blood lymphocytes from healthy donors, 3 reactive lymph nodes, and 1 normal thymus) and 6 cases of inflammatory dermatosis (pytiriasis lichenoides) was used as negative control. The Raji cell line was used as the positive control for the $\mathrm{p} 16^{\mathrm{INK} 4 \mathrm{a}}$ and $\mathrm{p} 15^{\mathrm{INK} 4 \mathrm{~b}}$ genes, and the L540 cell line for the p14 ARF gene. For analysis of allelic loss, nontumoral DNA was obtained from peripheral blood neutrophils (24 cases), oral swabs (7 cases), or nontumoral paraffin-embedded tissue (1 case).

Allelic Loss Assays at the 9p21 Locus. Tumoral and normal DNA was analyzed for $\mathrm{LOH}$ or HD by amplification of dinucleotide repeats containing sequence microsatellite markers, under conditions previously described by Villuendas et al (1998). These markers are at the 9p21 region, surrounding the p16 $16^{\mathrm{INK} 4 a}$, $\mathrm{p} 15^{\text {INK4b }}$, and $\mathrm{p} 14^{\mathrm{ARF}}$ genes (IFN- $\alpha$, D9S736, D9S1749, D9S1747, D9S974, D9S1748, D9S1752, D9S171). Amplification conditions were as described by Navas et al (2000) in a previously published report.

$\mathrm{LOH}$ was determined if the intensity of signal from any one allele was significantly reduced in the tumor DNA when compared with normal DNA by direct visualization. The presence of HD was also assessed in all cases, by comparative multiplex PCR assay using three primer sets from loci outside the 9p21 region (D9S934, D7S1824, and D7S460, in chromosomes $9 \mathrm{q}, 7 \mathrm{q}$, and $7 \mathrm{p}$, respectively).

Methylation Studies. DNA methylation patterns in the $\mathrm{CpG}$ islands of the first exon of $\mathrm{p} 15^{\mathrm{INK} 4 \mathrm{~b}}$, exon $1 \alpha$ of $\mathrm{p} 16^{\mathrm{INK} 4 \mathrm{a}}$, and exon $1 \beta$ of $\mathrm{p} 14^{\mathrm{ARF}}$ were determined by MSP assays (Herman et al, 1996a). DNA was modified with sodium-bisulfite as described in a previous report of our group (Navas et al, 2000). Bisulfitemodified DNA was amplified using $\mathrm{p} 16^{\mathrm{INK} 4 \mathrm{a}}, \mathrm{p} 15^{\mathrm{INK} 4 \mathrm{~b}}$, and $\mathrm{p} 14^{\mathrm{ARF}}$ unmethylated-specific primers $(\mathrm{U})$, methylated-specific primers (M), and unmodified or wild-type primers (W) (Herman et al, 1996a; Esteller et al, 2000).

Controls without DNA and positive controls for $U$ and $\mathrm{M}$ reactions were performed for each set of PCRs. The PCR product was visualized in agarose gels stained with ethidium bromide under ultraviolet illumination. If a methylation-specific PCR product was detected, the whole procedure using sodium bisulfite and MSP was performed again to minimize the possible influence of contamination or incomplete bisulfite treatment.

DNA methylation was determined by the presence of a 148-bp and 122-bp fragment in those samples amplified with the p15-M and p14-M primers, respectively (Herman et al, 1996a; Esteller et al, 2000). However, to confirm the findings with the initial p16-M primer set (150 bp) and to allow analysis of additional $\mathrm{CpG}$ sites in the promoter region, one additional primer set specific for the methylated sequence, p16-M2 (234 bp), was used in all cases (Herman et al, 1996a). DNA from the Raji and L540 cell lines was used as a positive control for the amplification reaction with the $\mathrm{p} 16-\mathrm{M} / \mathrm{M} 2$ and $\mathrm{p} 15-\mathrm{M}$ primers, and from the L540 cell line for the $\mathrm{p} 14^{\mathrm{ARF}}$ gene. 
Mutational Analysis of $p 16^{I N K 4 a}$ and p53 Genes. DNA from nine frozen tumoral stage samples was analyzed for mutations in exons 5 to 8 of the p53 gene and exons 1 and 2 of the p16 ${ }^{\text {INK4a }}$ gene, comprising $97 \%$ of the coding sequences, with primers and amplification conditions described previously (Villuendas et al, 1993, 1998). In both cases, direct sequencing of amplified products was performed with an Automated DNA Sequencer ABI PRISM 310 Genetic Analyzer (PE Applied Biosystems, Foster City, California) according to the manufacturer's procedures.

\section{Data Analysis}

Statistical analysis was performed by means of Epilnfo 6.02 or SAS software. The Wilcoxon and median score tests were used to compare the homogeneity of the epidemiologic data of the group of patients with stable or aggressive MF. The same tests were used to evaluate the influence of the epidemiologic data over the existence and type of $\mathrm{p} 16^{\mathrm{INK} 4 \mathrm{a}}$, $\mathrm{p} 15^{\mathrm{INK} 4 \mathrm{~b}}$, or $\mathrm{p} 14^{\mathrm{ARF}}$ genetic alteration.

The following characteristics were evaluated using Fisher's exact text or the $\chi^{2}$ test, with Yates' correction when necessary: treatment performed before the biopsy versus genetic alteration of the $\mathrm{p} 16^{\mathrm{INK} 4 \mathrm{a}}$, $\mathrm{p} 15^{\mathrm{INK} 4 \mathrm{~b}}$, or $\mathrm{p} 14^{\mathrm{ARF}}$ genes; and differences in $\mathrm{p} 16^{\mathrm{INK} 4 \mathrm{a}}$, $\mathrm{p} 15^{\mathrm{INK} 4 \mathrm{~b}}$, or $\mathrm{p} 14^{\mathrm{ARF}}$ genetic alteration among the three groups of lesions (stable MF and aggressive MF before and after tumoral transformation).

\section{Acknowledgements}

We would like to thank Dr. Agustín Gómez for his useful help with statistical analysis and Dr. Pablo Morales for his kind contribution of patient samples.

\section{References}

Algara P, Soria C, Martínez P, Sánchez L, Villuendas R, García P, López C, Orradre JL and Piris MA (1994). Value of PCR detection of TCR gamma gene rearrangement in the diagnosis of cutaneous lymphocytic infiltrates. Diagn Mol Pathol 3:275-282.

Aggerholm A, Guldberg P, Hokland M, and Hokland P (1999). Extensive intra- and interindividual heterogeneity of p15INK4b methylation in acute myeloid leukemia. Cancer Res 59:436-441.

Asadullah K, Docke WD, Haeussler A, Sterry W, and Volk HD (1996). Progression of mycosis fungoides is associated with increasing cutaneous expression of interleukin-10 mRNA. J Invest Dermatol 107:833-837.

Baur AS, Shaw P, Burri N, Delacrétaz F, Bosman FT, and Chaubert $P$ (1999). Frequent methylation silencing of p15 INK4b $\left(\right.$ MTS2) and p16 $6^{\text {INK4a }}$ (MTS1) in B-cell and T-cell lymphomas. Blood 94:1773-1781.

Cairns P, Polascik TJ, Eby Y, Tokino K, Califano J, Merlo AA, Mao L, Herath J, Jenkins R, Westra W, Rutter JL, Buckler A, Gabrielson E, Tockman M, Cho KR, Hedrick L, Bova GS, Isaacs W, Koch W, Schwab D, and Sidransky D (1995). Frequency of homozygous deletion at p16/CDKN2 in primary human tumours. Nat Genet 11:210-212.
Cameron E, Baylin SB, and Herman JG (1999). P15 INK4b $\mathrm{CpG}$ island methylation in primary acute leukemia is heterogeneous and suggests density as a critical factor for transcriptional silencing. Blood 94:2445-2451.

Carnero A, Hudson JD, Price CM, and Beach DH (2000). P16INK4a and p19ARF act in overlapping pathways in cellular immortalization. Nat Cell Biol 2:148-155.

Ching L, Pomerantz J, and DePinho RA (1998). The INKAa/ ARF tumour suppresser: One gene-two products-two pathways. Trends Biochem Sci 23:291-296.

Cohen JA and Geradts J (1997). Loss of Rb and MTS1/ CDKN2 (p16) expression in human sarcomas. Human Pathol 28:893-898.

de Misa RF, Azana JM, Harto A, Bellas C, and Ledo A (1995). Infrequent expression of protein p53 in epidermotropic variants of cutaneous T-cell lymphomas. J Dermatol 22:524526.

Diamandidou E, Cohen PR, and Kurzrock R (1996). Mycosis fungoides and Sézary syndrome. Blood 88:2385-2409.

Drexler HG (1998). Review of alterations of the cyclin dependent kinase inhibitor INK4 family genes p15, p16, p18 and p19 in human leukemia-lymphoma cells. Leukemia 12:845849 .

Elenitoba-Johnson KS, Gascoyne RD, Lim MS, Chhanabai M, Jaffe ES, and Raffelfd M (1998). Homozygous deletions at chromosome 9p21 involving p16 and p15 are associated with histologic progression in follicle centre lymphoma. Blood 91:4677-4685.

Esteller M, Tortola S, Toyota M, Capella G, Peinado MA, Baylin SB, and Herman J (2000). Hypermethylationassociated inactivation of p14ARF is independent of p16INK4a methylation and p53 mutational status. Cancer Res 60:129-133.

Fernandez-Piqueras J, Santos J, Perez de Castro I, Meléndez B, Martínez B, Robledo M, Rivas C, and Benítez J (1997). Frequent allelic losses of 9p21 markers and low incidence of mutations at p16 (CDKN2) gene in NHL of B-cell lineage. Cancer Genet Cytogenet 98:63-68.

Garatti SA, Roscetti E, Trecca D, Fracchiolla NS, Neri A, and Berti E (1995). bcl1, bcl2, p53, c-myc, and lyt-10 analysis in cutaneous lymphomas. Recent Results Cancer Res 139: $249-261$.

Gardie B, Cayuela JM, Martini S, and Sigaux F (1998). Genomic alterations of the p19ARF encoding exons in T-cell acute lymphoblastic leukemia. Blood 91:1016-1020.

Geradts J, Andriko JW, and Abbondanzo SL (1998). Loss of tumor suppressor gene expression in high-grade but not low-grade non-Hodgkin's lymphomas. Am J Clin Pathol 109:669-674.

Geradts J, Kratzke RA, Niehans GA, and Lincoln CE (1995). Immunohistochemical detection of the cyclin-dependent kinase inhibitor 2/multiple tumor suppressor gene 1 (CDKN2/ MTS1) product p16INK4A in archival human solid tumors: Correlation with retinoblastoma protein expression. Cancer Res 55:6006-6011.

Gombart AF, Morosetti R, Miller CW, Said JW, and Koeffler HP (1995). Deletions of the cyclin-dependent kinase inhibitor genes p16INK4A and p15INK4B in non-Hodgkin's lymphomas. Blood 86:1534-1539. 
Gulley ML, Nicholls JM, Schneider BG, Amin MB, Ro JY, and Geradts J (1998). Nasopharyngeal carcinomas frequently lack the p16/MTS1 tumor suppressor protein but consistently express the retinoblastoma gene product. Am J Pathol 152:865-869.

Hannon GJ and Beach D (1994). p15INK4B is a potential effector of TGF- $\beta$-induced cell cycle arrest. Nature 371:257261.

Herman JG, Civin CI, Issa J-PJ, Collector MI, Sharkis SJ, and Baylin SB (1997). Distinct patterns of inactivation of $p 15^{\text {INK4b }}$ and $\mathrm{p} 16^{\mathrm{INK} 4 \mathrm{a}}$ characterize the major types of hematological malignancies. Cancer Res 57:837-841.

Herman JG, Graff JR, Myöhänen S, Nelkin BD, and Baylin SB (1996a). Methylation-specific PCR: A novel PCR assay for methylation status of $\mathrm{CpG}$ islands. Proc Natl Acad Sci USA 93:9821-9826.

Herman JG, Jen J, Merlo A, and Baylin SB (1996b). Hypermethylation-associated inactivation indicates a tumor suppressor role for p15INK4b. Cancer Res 56:722-727.

Kamb A, Gruis NA, Weaver-Feldhaus J, Liu Q, Harshman K, Tavtigian SV, Stockert E, Day RS III, Johnson BE, and Skolnick MH (1994). A cell cycle regulator potentially involved in genesis of many type of tumors. Science 264:436-440.

Kamijo T, Weber JD, Zambetti G, Zindy F, Roussel MF, and Sherr CJ (1998). Functional and physical interactions of the ARF tumour suppresser with p53 and MDM2. PNAS 95: 8292-8297.

Klangby U, Okan I, Magnusson KP, Wendland M, Lind P, and Wiman KG (1998). P16/INK4a and p15/INK4b gene methylation and absence of $\mathrm{p} 16 / \mathrm{INK} 4 \mathrm{a}$ mRNA and protein expression in Burkitt's lymphoma. Blood 91:1680-1687.

Koduru PRK, Zariwala M, Soni M, Gong JZ, Xiong Y, and Broome JD (1995). Deletion of cyclin-dependent kinase 4 inhibitor genes p15 and p16 in NHL. Blood 86:2900-2905.

Kratzke RA, Greatens TM, Rubins JB, Maddaus MA, Niewoehner DE, Niehans GA, and Geradts J (1996). Rb and p16INK4a expression in resected non-small cell lung tumors. Cancer Res 56:3415-3420.

Lohrum MAE, Ashcroft M, Kubbutat MHG, and Vousden KH (2000). Identification of a cryptic nucleolar-localization signal in MDM2. Nat Cell Biol 2:179-181.

Marrogi AJ, Khan MA, Vonderheid EC, Wood GS, and McBurney E (1999). p53 tumor suppressor gene mutations in transformed cutaneous $\mathrm{T}$ cell lymphoma: A study of 12 cases. J Cutan Pathol 26:369-378.

Martínez-Delgado B, Robledo M, Arranz E, Osorio A, García MJ, Echezarreta G, Rivas C, and Benítez J (1998). Hypermethylation of p15/ink4b/MTS2 gene is differentially implicated among non-Hodgkin's lymphomas. Leukemia 12:937941.

Navas IC, Ortiz-Romero PL, Villuendas R, Martínez P, García C, Gómez E, Rodriguez JL, García D, Vanaclocha F, Iglesias L, Piris MA, and Algara $P(2000) . p 16^{\text {INK4a }}$ gene alterations are frequent in lesions of mycosis fungoides. Am J Pathol 150: 1565-1572.

$\mathrm{Ng} \mathrm{MHL,} \mathrm{Chung} \mathrm{YF,} \mathrm{Lo} \mathrm{KW,} \mathrm{Wickham} \mathrm{NWR,} \mathrm{Lee} \mathrm{JCK,} \mathrm{and}$ Huang DP (1997). Frequent hypermethylation of p16 and p15 genes in multiple myeloma. Blood 89:2500-2506.
Ng MHL, Wong IHN, and Lo KW (1999). DNA methylation changes and multiple myeloma. Leuk Lymphoma 34:463472 .

Ogawa S, Hangaishi A, Miyawaki S, Hirosawa S, Miura Y, Takeyama K, Kamada N, Ohtake S, Uike N, Shimazaki C, Toyama K, Hirano M, Mizoguchi H, Kobayashi Y, Furusawa S, Saito M, Emi N, Yazaki Y, Ueda R, and Hirai H (1995). Loss of the cyclin-dependent kinase 4-inhibitor (p16;MTS1) gene is frequent in and highly specific to lymphoid tumors in primary human hematopoietic malignancies. Blood 86:15481556.

Okuda T, Shurtleff SA, Valentine MB, Raimondi SC, Head DR, Behm F, Curcio-Brint AM, Liu Q, Pui C-H, Sherr CJ, Beach D, Look AT, and Downing JR (1995). Frequent deletion of p16 INK4a/MTS1 and p15INK4b/MTS2 in pediatric acute lymphoblastic leukemia. Blood 85:2321-2330.

Peris K, Stanta G, Fargnoli MC, Bonin S, Felli A, Amantea A, and Chimenti $S$ (1999). Reduced expression of CDKN2a/ p16 ${ }^{\text {INK4a }}$ in mycosis fungoides. Arch Dermatol Res 291:207211.

Pinyol M, Cobo F, Bea S, Jares P, Nayach I, Fernández PL, Montserrat E, Cardesa A, and Campo E (1998). p16 ${ }^{\text {INK4a }}$ gene inactivation by deletions, mutations and hypermethylation is associated with transformed and aggressive variants of nonHodgkin's lymphomas. Blood 91:2977-2984.

Pomeranntz J, Schreiber-Agus N, Liégeois NJ, Silverman A, Alland L, Chin L, Potes J, Chen K, Orlow I, Lee H-W, Cordon-Cardo C, and DePinho RA (1998). The INK4a tumour suppresser gene product, p19ARF, interacts with MDM2 and neutralizes MDM2's inhibition of p53. Cell 92:713-723.

Quelle DE, Cheng M, Ashmun RA, and Sherr CJ (1997). Cancer-associated mutations at the INK4a locus cancel cell cycle arrest by $\mathrm{p} 16 \mathrm{INK} 4 \mathrm{a}$ but not the alternative reading frame protein p19ARF. Proc Natl Acad Sci USA 94:669-673.

Reed AL, Califano J, Cairns P, Westra WH, Jones RM, Koch W, Ahrendt S, Eby $\mathrm{Y}$, Swell D, Nawroz H, Bartek J, and Sidransky D (1996). High frequency of p16 (CDKN2/MTS-1/ INK4a) inactivation in head and neck squamous cell carcinoma. Cancer Res 56:3630-3633.

Rook AH, Gottlieb SL, Wolfe JT, Vowels BR, Sood SS, Niu Z, Lessin SR, and Fox FE (1997). Pathogenesis of cutaneous T-cell lymphoma: implications for the use of recombinant cytokines and photopheresis. Clin Exp Immunol 107(Suppl 1):16-20.

Scarisbrick JJ, Woolford AJ, Russell-Jones R, and Whittaker SJ (2000). Loss of heterozygosity on $10 q$ and microsatellite instability in advanced stages of primary cutaneous T-cell lymphoma and possible association with homozygous deletion of PTEN. Blood 95:2937-2942.

Serrano M (1997). The tumour suppresser protein $\mathrm{p} 16^{\mathrm{INK} 4 \mathrm{a}}$. Exp Cell Res 237:7-13.

Sherr CJ (1996). Cancer cell cycle. Science 274:1672-1677.

Siebert R, Willers CP, Schramm A, Fossa A, Dresen IM, Uppenkamp M, Nowrousian MR, Seeber S, and Opalka B (1995). Homozygous loss of the MTS1/p16 and MTS2/p15 genes in lymphoma and lymphoblastic leukaemia cell lines. $\mathrm{Br} \mathrm{J}$ Haematol 91:350-354.

Stranks G, Height SE, Mitchell P, Jadayel D, Yuille MA, De Lord C, Clutterbuck RD, Treleaven JG, Powles RL, Nacheva E, Oscier DG, Karpas A, Lenoir GM, Smith SD, Millar JL, 
Catovsky D, and Dyer MJS (1995). Deletions and rearrangement of CDKN2 in lymphoid malignancy. Blood 85:893-901.

Uchida T, Watanable T, Kinoshita T, Murate T, Saito H, and Hotta T (1995). Mutational analysis of the CDKN2 (MTS1/ p16INK4a) gene in primary B-cell lymphomas. Blood 86: 2724-2731.

Villuendas R, Piris MA, Algara $P$, Sánchez-Beato $M$, Sánchez-Verde L, Martínez JC, Orradre JL, García P, López C, and Martínez P (1993). The expression of p53 protein in $\mathrm{NHL}$ lymphomas is not always dependent on p53 gene mutations. Blood 82:3151-3156.

Villuendas R, Sánchez-Beato M, Martínez JC, Sáez AI, Martínez-Delgado B, García JF, Mateo MS, Sánchez-Verde L, Benítez J, Martínez P, and Piris MA (1998). Loss of p16/INK4A protein expression in non-Hodgkin's lymphomas is a frequent finding associated with tumour progression. Am J Pathol 153:887-897.
Weber JD, Taylor LJ, Roussel MF, Sherr CJ, and Bar-Sagi D (1999). Nucleolar ARF sequesters MDM2 and activates p53. Nat Cell Biol 1:20-26.

Wijermans P, Lubbert M, Verhoef G, Bosly A, Ravoet C, Andre M, and Ferrant A (2000). Low dose 5-aza-2'deoxycytidine, a DNA hypomethylating agent for the treatment of high-risk myelodysplastic syndrome: A multicenter phase II study in elderly patients. J Clin Oncol 18:956-962.

Zhang Y, Xiong Y, and Yarbrough WG (1998). ARF promotes MDM2 degradation and stabilizes p53: ARF-INK4a locus deletion impairs both the $\mathrm{Rb}$ and $\mathrm{p} 53$ tumor suppression pathways. Cell 92:725-734. 